\title{
Environmentally Smart Nitrogen Performance in Northern Great Plains' Spring Wheat Production Systems
}

\author{
Olga S. Walsh and Kefyalew Girma \\ Southwest Research \& Extension Center, University of Idaho, 29603 U of I Lane, Parma, ID 83660-6699, USA \\ Correspondence should be addressed to Olga S. Walsh; owalsh@uidaho.edu
}

Received 29 October 2015; Accepted 3 March 2016

Academic Editor: Glaciela Kaschuk

Copyright ( 12016 O. S. Walsh and K. Girma. This is an open access article distributed under the Creative Commons Attribution License, which permits unrestricted use, distribution, and reproduction in any medium, provided the original work is properly cited.

Experiments were conducted in Montana to evaluate Environmentally Smart Nitrogen (ESN) as a nitrogen (N) source in wheat. Plots were arranged in a split-plot design with ESN, urea, and a 50\%-50\% urea-ESN blend at low, medium, and high at-seeding $\mathrm{N}$ rates in the subplot, with four replications. Measurements included grain yield (GY), protein (GP), and N uptake (GNU). A partial budget economic analysis was performed to assess the net benefits of the three sources. Average GY varied from 1816 to $5583 \mathrm{~kg} \mathrm{ha}^{-1}$ and grain protein (GP) content ranged from 9.1 to $17.3 \%$ among site-years. Urea, ESN, and the blend resulted in higher GYs at 3, 2, and 2 site-years out of 8 evaluated site-years, respectively. Topdressing N improved GY for all sources. No trend in GP associated with $\mathrm{N}$ source was observed. With GP-adjusted revenue, farmer would not recover investment costs from ESN or blend compared with urea. With ESN costing consistently more than urea per unit of $\mathrm{N}$, we recommend urea as $\mathrm{N}$ source for spring wheat in Northern Great Plains.

\section{Introduction}

To address the nutritional needs of the fast-growing human population, the annual cereal production will have to increase to about 3 billion tones by 2050 from currently produced 2.1 billion tones [1]. It was shown that 80 percent of the required crop production increases will have to come from improved GY and crop intensification versus only 20 percent from expansion of agricultural land $[1,2]$. Furthermore, the concern is that the rate of growth in cereal GY has been steadily declining worldwide.

The reports indicate that the rate of growth of major cereals has dropped from 3.2 percent per year in the 1960s to only 1.5 percent in $2000[1,2]$. Although the genetics and biotech industries estimated their ability to increase cereal GYs due to genetic GY potential of 3 to $4 \%$ per year [3], history indicates that the genetic advances alone may not be sufficient to solve the world's food shortage issues [4]. At least $50 \%$ of food currently produced in the world is possible due to use of commercial N, phosphorus (P), and potassium (K) fertilizer [5]. Roberts [4] pointed out the critical role the fertilizers play in the world's food security and underlined the close correlation between global cereal crop production and fertilizer consumption. Consequently, the fertilizer use is estimated to increase dramatically worldwide at an expected rate of 2.5 million metric tons per year [6].

Nitrogen use efficiency (NUE), the ratio of the difference of $\mathrm{N}$ uptake in the $\mathrm{N}$ treated plot and $\mathrm{N}$ uptake in the check and the total applied $\mathrm{N}$ rate, is only at 40 to $50 \%$ for most crop production systems [7]. A considerable improvement from the previously estimated 33\% NUE in the late 1990s [8] is mainly due to advances in precision agriculture and novel fertilizer technologies [9]. Developing an effective and efficient $\mathrm{N}$ management strategy and improving $\mathrm{N}$ guidelines are the key challenges that must be addressed to maintain and enhance the sustainability of cereal crop production. Identifying practical solutions for reducing agricultural input costs such as fertilizer is critical for maintaining soil fertility and improving productivity for crop growers [10].

The Northern Great Plains is the key region for production of top quality spring wheat grain. Spring wheat continues to be one of the major cereal crops for Montana and North Dakota, which account approximately for 20 and 44\%, respectively, of all spring wheat produced in the United States 
[11]. Not considering water, inadequate $\mathrm{N}$ nutrition is considered to be the most GY-limiting factor in wheat production [12].

The awareness and interest to enhanced-efficiency fertilizer technologies among the Northern Great Plains producers are apparent. This trend is mainly due to steady efforts to improve the efficiency of fertilizer use and to minimize the negative impact of intensive agricultural production on the environment. The key to both increasing NUE and reducing $\mathrm{N}$ losses is the synchronization of $\mathrm{N}$ availability with the crop requirements [10], which has been the basis of many enhanced-efficiency fertilizers [13]. Shaviv [14] has proposed that enhanced-efficiency fertilizers could be effectively used to improve synchrony between soil $\mathrm{N}$ availability and crop uptake requirements for $\mathrm{N}$. The enhanced-efficiency fertilizer products can reduce nutrient losses to the environment and deliver improved availability of nutrients to the crop [15].

Environmentally Smart Nitrogen (ESN), a common enhanced-efficiency fertilizer, is produced by coating urea granules with a polymer shell that allows for a slow-release of $\mathrm{N}$ to the soil. Literature review points to numerous studies showing that higher GYs and better crop quality could be achieved with ESN compared to conventional urea providing crop producers with a higher return on their fertilizer investment $[16,17]$. Furthermore, due to the slow-release technology, the increase in NUE is achieved by reduction of $\mathrm{N}$ losses through denitrification, leaching, and volatilization. In the recent years, the interest in use of the enhanced-efficiency fertilizers has increased due to their potential to reduce negative environmental impact $[18,19]$ observed improved GY and significantly lower $\mathrm{N}$ losses with sidedress ESN application to corn.

Recently, enhanced-efficiency fertilizers have been defined as "fertilizer products with characteristics that allow increased plant uptake and reduce the potential of nutrient losses to the environment (e.g., gaseous losses, leaching, or runoff) when compared to an appropriate reference product" by the Association of American Plant Food Control Officials [20]. Numerous reports showed that enhanced-efficiency fertilizer products can decrease the nitrous oxide $\left(\mathrm{N}_{2} \mathrm{O}\right)$ emission rate from soils, especially immediately after fertilizer application [18].

The Environmental Protection Agency (EPA) estimated that, in 2012, $\mathrm{N}_{2} \mathrm{O}$ accounted for about $6 \%$ of all US greenhouse gas emissions associated with human activities; agricultural activities account for approximately $75 \%$ of all $\mathrm{N}_{2} \mathrm{O}$ emissions [21]. Halvorson et al. [22] observed a $42 \%$ reduction in $\mathrm{N}_{2} \mathrm{O}$ emissions compared to traditional urea (46-00 ). Hatfield and Parkin [23] suggested that the increase in GY could be due to prolonged period of greenness in crops, especially during the grain-filling period. Furthermore, the use of enhanced-efficiency fertilizers such as ESN resulted in improved NUE, demonstrating positive environmental and agronomic advantages. Because the ESN was formulated to minimize $\mathrm{N}$ loss, ESN application is considered an environmentally sound farming practice.

In the USA the growers using ESN are eligible for payments through the Environmental Quality Incentives Program (EQIP), which helps to offset the higher cost of ESN compared to traditional uncoated urea. The ESN also may be beneficial for producers in complying with tighter environmental regulations, shorter crop seeding windows, and adverse weather conditions [24].

Some consider the ESN as a controlled release $\mathrm{N}$ fertilizer $[25,26]$ that supplies the crop with $\mathrm{N}$ all throughout the growing season [13]. Moreover, the manufacturer affirms that ESN offers a predictable release of $\mathrm{N}$ due to the coating characteristics. The polymer coating represents a semipermeable membrane that allows water to diffuse into the granule and dissolve $\mathrm{N}$; encapsulated $\mathrm{N}$ remains inside and is released over time at a controlled rate [25].

The $\mathrm{N}$ release rate is controlled by soil temperature; $\mathrm{N}$ release rate increases as the soils temperatures rise in the spring. This methodology aims to match crop need for $\mathrm{N}$ by "spoon-feeding" it with gradual $\mathrm{N}$ release from the ESN capsules. However, others tend to classify ESN simply as a slow-release product $[27,28]$ due to uncertainty in the level of control provided by the polymer coating. In fact, as water diffuses through a flexible, microthin polymer coating, the liquefied $\mathrm{N}$ is allowed to disperse out through the membrane and into the soil [29].

The common variations in soil characteristics and temperatures must be also considered. Soil and air temperatures, as well as crop development rate, do not increase linearly throughout the growing season. In most cropping systems, warmer/colder periods are likely; the speed of crop growth is known to vary considerably depending on the developmental growth stage. For instance, stem elongation (Zadoks 30-39) is the most rapid stage of wheat crop growth, resulting in much faster vegetative tissue growth and biomass production compared to other growth stages [30].

Studies conducted in a variety of crops have indicated that weather conditions, soil characteristics, application time, method, and crop rotations are the major factors influencing the effectiveness of the enhanced-efficiency [31-34]. Studies have shown that as all $\mathrm{N}$ has been dissolved within the ESN casing and the soil temperatures reach $20^{\circ} \mathrm{C}$, between 65 and $90 \%$ of $\mathrm{N}$ is released into the soil within a 30 -day period [35]. Also, a comprehensive assessment of $\mathrm{N}$ release from the ESN granules revealed that the rate of $\mathrm{N}$ release is highly dependent on the soil type. A more rapid release of $\mathrm{N}$ was observed in clay soils compared with silt and sandy loam soils [35].

To meet a producers' GY and quality targets for specific crops and growing conditions, ESN can be used as a sole $\mathrm{N}$ source or as a blend with other fertilizers such as traditional urea. Typically, ESN blended with other soluble N products performs best as spring preplant applications in spring wheat. Research in potato also has shown that a one-time application of ESN can be as cost effective as multiple in-season applications of traditional $\mathrm{N}$ products with fertigation [36]. Better or similar potato GYs were observed with a single application of ESN (even when 25\% less $\mathrm{N}$ was applied), compared to those obtained with the split urea application [37].

The ESN recommendations for a wide variety of field crops such as corn, canola, cotton, and wheat have been developed by the manufacturer. The manufacturer's guidelines for ESN use in spring wheat in the Great Plains area are application of $\mathrm{N}$ as $100 \% \mathrm{ESN}$ in the fall prior to seeding. 
TABLE 1: Initial soil chemical properties $(0-30 \mathrm{~cm})$, growing conditions, and summary of field activities at Conrad, Corvallis, and Kalispell, MT, in 2011-2013.

\begin{tabular}{|c|c|c|c|}
\hline Field activity & 2011 & $\begin{array}{c}2012 \\
\text { Conrad }\end{array}$ & 2013 \\
\hline Herbicide & GoldSky & GoldSky, Huskie & GoldSky, Huskie \\
\hline Herbicide date & May 31 & May 16 & May 23 \\
\hline Sensing date & June 15 & May 18 & May 13 \\
\hline Topdress N date & June 15 & May 21 & May 14 \\
\hline Harvest date & August 30 & August 16 & September 10 \\
\hline Soil test $\mathrm{N}, \mathrm{kg} \mathrm{ha}^{-1}$ & 22 & 56 & 51 \\
\hline Soil P, ppm (Olson) & 18 & 12 & 32 \\
\hline Soil K, ppm & 221 & 152 & 234 \\
\hline Organic matter, $\%$ & 1.5 & $\begin{array}{c}1.2 \\
\text { Corvallis }\end{array}$ & 1.8 \\
\hline Herbicide & Bronate, Axial XL & Bronate, Axial XL & Supremacy, Axial XL \\
\hline Herbicide date & June 13 & May 28 & May 28 \\
\hline Sensing date & June 15 & June 8 & June 5 \\
\hline Topdress N date & June 15 & June 8 & June 5 \\
\hline Harvest date & September 8 & August 16 & August 19 \\
\hline Soil test $\mathrm{N}, \mathrm{kg} \mathrm{N} \mathrm{ha}{ }^{-1}$ & 37.5 & 44.3 & 51.6 \\
\hline Soil P, ppm & 23 & 23 & 25 \\
\hline Soil K, ppm & 423 & 423 & 398 \\
\hline Organic matter, $\%$ & 2.9 & $\begin{array}{c}2.9 \\
\text { Kalispell }\end{array}$ & 2.2 \\
\hline Herbicide & Bronate, Axial XL & Bronate, Axial XL & - \\
\hline Herbicide date & June 13 & May 28 & - \\
\hline Sensing date & June 15 & June 8 & - \\
\hline Topdress $\mathrm{N}$ date & June 15 & June 8 & - \\
\hline Harvest date & September 8 & August 16 & - \\
\hline Soil test $\mathrm{N}, \mathrm{kg} \mathrm{N} \mathrm{ha}^{-1}$ & 37.5 & 44.3 & - \\
\hline Soil P, ppm & 23 & 23 & - \\
\hline Soil K, ppm & 423 & 425 & - \\
\hline Organic matter, \% & 2.8 & 2.9 & - \\
\hline
\end{tabular}

Alternatively, spring wheat can be fertilized with a blend (40-75\% ESN + 25-60\% urea) [25]. This paper summarizes the results from a three-year-long study that compared the effect of ESN and urea-ESN blend with urea, for spring wheat production in the Northern Great Plains. The specific objectives of the study were to evaluate urea, ESN, and ESNurea blend along at-seeding and topdress $\mathrm{N}$ rates on spring wheat production, quality, and economic return in Montana.

\section{Materials and Methods}

2.1. Experimental Sites and Treatment Structure. Three field studies were initiated in the spring of 2011 and completed in the 2013 growing season (eight site-years). Field trials were conducted at one irrigated site, at Western Agricultural Research Center (Corvallis, $46^{\circ} 19^{\prime} 39.8532^{\prime \prime}$, $\left.-114^{\circ} 05^{\prime} 08.6496^{\prime \prime}\right)$ and two dryland sites at the North Western Agricultural Research Center (Kalispell, $48^{\circ} 11^{\prime} 14.4312^{\prime \prime}$, $-114^{\circ} 08^{\prime} 04.7436^{\prime \prime}$ ) and at the Western Triangle Agricultural Research Center (Conrad, $48^{\circ} 19^{\prime} 11.6868^{\prime \prime},-111^{\circ} 55^{\prime} 28.7256^{\prime \prime}$ ).

The soils at Conrad, Corvallis, and Kalispell are Scobey clay loam (fine, smectitic, frigid Aridic Argiustolls), burnt fork loam (coarse-loamy, mixed, superactive, frigid Typic Haplustolls), and Creston silt loam (fine-silty, mixed, superactive Typic Haploborolls), respectively. Initial soil properties, growing conditions, and field activities are presented in Table 1.

Plots were arranged in a split-plot design with three $\mathrm{N}$ sources and at-seeding $\mathrm{N}$ rates in the main plot and topdress $\mathrm{N}$ in the subplot. An additional control $\left(0 \mathrm{~kg} \mathrm{Nha}^{-1}\right)$ treatment was included outside the factorial in the main plot. Each treatment was replicated 4 times at each site-year. The three $\mathrm{N}$ sources were urea, ESN, and a 50:50 blend of urea and ESN. The at-seeding $\mathrm{N}$ fertilizer rates were 56,112 , and $168 \mathrm{~kg} \mathrm{~N} \mathrm{ha}^{-1}$ at Conrad and 112, 224, and $336 \mathrm{~kg} \mathrm{~N} \mathrm{ha}^{-1}$ at Corvallis and Kalispell, representing low, medium, and 
high $\mathrm{N}$ rates, respectively, for each site. The at-seeding $\mathrm{N}$ rates were established based on the respective area's GY goal and current Montana State University's N fertilization guidelines for spring wheat. The topdress $\mathrm{N}$ was applied at 0 or $45 \mathrm{~kg} \mathrm{~N} \mathrm{ha}^{-1}$ as granular broadcasted urea at Zadoks 30 (late tillering/beginning of stem elongation) growth stage.

Hard red spring wheat (cv. Choteau) was seeded into plots measuring 1.5 by $7.6 \mathrm{~m}$ at the seeding rate of $1,830,000$ plants $\mathrm{ha}^{-1}$ for dryland sites and from 2,150,000 to 3,225,000 plants per ha ${ }^{-1}$ at the irrigated site, using the custom-made direct-seed drill with Conserva $\mathrm{Pak}^{\mathrm{TM}}$ openers manufactured by Swift Machining (Washougal, WA). At-seeding N fertilizer was sidebanded about $1.90 \mathrm{~cm}$ to the side and about $2.54 \mathrm{~cm}$ above the seed.

2.2. Measurements. At maturity, spring wheat was harvested with Hege 125 plot combine in 2011 and 2012 and Wintersteiger classic plot combine in 2013. The harvested grain was dried in the drying room for 14 days at the temperature of $35^{\circ} \mathrm{C}$; then, the by-plot GY was determined. From each byplot sample, $400 \mathrm{~g}$ subsample was drawn and analyzed by the Agvise Laboratories (Northwood, ND) for total grain $\mathrm{N}$ content using near infrared reflectance spectroscopy (NIR) with a Perten DA 7250 NIR analyzer (Perten Instruments, Inc., Springfield, IL).

From the GY and lab analysis results, grain $\mathrm{N}$ uptake (GNU) was determined using the following relationship:

$$
\mathrm{GNU}=\mathrm{GY} * \mathrm{~N} \text { content of grain. }
$$

Furthermore, GP of spring wheat was calculated by multiplying the $\mathrm{N}$ content of grain by 6.5 .

2.3. Statistical Analysis. All data were subjected to analysis of variance (ANOVA) using GLIMMIX procedure in SAS (SAS version 9.4, Cary, NC, USA). Before testing hypotheses, assumptions of normality and homogeneity of variance were checked for all measured variables using the UNIVARIATE procedure and Levene's Homogeneity of Variance Test, respectively. Very few outliers were identified and removed from the data.

After preliminary statistical analysis showed a significant site and year effects, data were analyzed for each site-year. In this three-factor study, the focus was on the two-way interaction effects (plus selected three-way interactions) of sources with at-seeding and topdress $\mathrm{N}$ rate treatment levels rather than the main effects. Whenever interactions were significant, tests of simple effects were generated and further dissected using the "slice" option under the least square (LS) means statement [38] in GLIMMIX for each factor level, at fixed level of the other factor. The test produces $F$ value by extracting the appropriate rows from the coefficient matrix for each two-way interaction simple effect LS means [38, 39]. Then the "lines" statement under LS means statement was used to generate letter based pairwise LS means differences at $p<0.05$ if not specified for each response variable.

Additionally, orthogonal polynomial contrasts were used to assess trends (linear and quadratic) in response variables against increasing rates of at-seeding $\mathrm{N}$ rate main effects and their interaction effect with source or topdress $\mathrm{N}$ levels when significant at least at $p<0.1$. Pearson product-moment correlation [40] analysis was used to assess the relationship of GY and GP. Pearson's correlation was performed for each site-year. If no significant interaction effects were observed, then main effects were discussed.

2.4. Partial Budget Economic Analysis. A partial budget economic analysis [41] was performed to assess the net benefits of the three sources. The marginal benefit and rate of return [42] of the ESN and blend relative to $\mathrm{N}$ from urea were also evaluated, using the optimum $\mathrm{N}$ rates for each significant siteyear $\left(168 \mathrm{~kg} \mathrm{~N} \mathrm{ha}^{-1}\right.$ at Conrad and $224 \mathrm{~kg} \mathrm{~N} \mathrm{ha}^{-1}$ at Corvallis and Kalispell, Table 2). An additional partial budget analysis was performed to compare ESN at medium at-seeding $\mathrm{N}$ rate with urea at low at-seeding $\mathrm{N}$ rate along topdress $\mathrm{N}$ rate. For this analysis the medium at-seeding rates were 112 and $224 \mathrm{~kg} \mathrm{~N} \mathrm{ha}^{-1}$ at Conrad and Kalispell, respectively. The low at-seeding rates were 56 and $112 \mathrm{~kg} \mathrm{Nha}^{-1}$ at Conrad and Kalispell, respectively, along $45 \mathrm{~kg} \mathrm{ha}^{-1}$ topdress $\mathrm{N}$. The calculation assumed spring wheat grain GY price unadjusted and adjusted for GP premium and discount. Premium and discount values were obtained from West-Con Cooperative [43]. Price of wheat was set at $\$ 0.17 \mathrm{~kg}^{-1}$ [44]. Current price of $\mathrm{N}$ in urea and $\mathrm{ESN}$ was set at $\$ 1.31$ and $1.71 \mathrm{~kg}^{-1}$, respectively [45]. The cost of mixing urea and ESN blend was estimated at $\$ 3 \mathrm{ha}^{-1}$. The cost of topdress application of $\mathrm{N}$ was set to be $\$ 15.2 \mathrm{ha}^{-1}$. Partial budget equations were defined as follows [42]:

$$
\begin{aligned}
\mathrm{NR} & =\mathrm{TR}-\mathrm{TVC}, \\
\Delta \mathrm{NR} & =\Delta \mathrm{TR}-\Delta \mathrm{TVC}, \\
\mathrm{MRR} & =\frac{\Delta \mathrm{TR}}{\Delta \mathrm{TVC}},
\end{aligned}
$$

where NR is net return, TR is total revenue, TVC is total variable cost, and $\Delta \mathrm{NR}, \Delta \mathrm{TR}$, and $\triangle \mathrm{TVC}$ represent the change in net return, change in total revenue, and change in total variable cost due to ESN and ESN-urea blend, respectively, and $\mathrm{RR}$ is the rate of return that measures the dollar recovery to a dollar investment on ESN or blend.

\section{Results}

3.1. Grain Yield. In 2011, the lowest GY was observed at Conrad $\left(2488 \mathrm{~kg} \mathrm{ha}^{-1}\right)$, followed by Corvallis (2623 to $\left.3161 \mathrm{~kg} \mathrm{ha}^{-1}\right)$. Grain yield at Kalispell was the highest among the three experimental sites, ranging from 2898 to $4237 \mathrm{~kg} \mathrm{ha}^{-1}$. In 2012, GY was the highest among the three growing seasons for all experimental locations. Conrad was the highest producing site with GY ranging from 4035 to $5583 \mathrm{~kg} \mathrm{ha}^{-1}$. The GY for Kalispell and Corvallis was comparable but slightly higher at Corvallis. In 2013, GY was higher at Conrad (3699 to $4640 \mathrm{~kg} \mathrm{ha}^{-1}$ ) than Corvallis (1816 to $2623 \mathrm{~kg} \mathrm{ha}^{-1}$ ).

Nitrogen source affected GY significantly at Conrad in 2012 and Corvallis and Kalispell in 2011 (Table 2). At Conrad, ESN surpassed urea by $405 \mathrm{~kg} \mathrm{ha}^{-1}$. At Corvallis, 
TABLE 2: Effect of N source and preplant and topdress N rate on spring wheat grain yield at Conrad, Corvallis, and Kalispell, MT, in 2011-2013 growing seasons.

\begin{tabular}{|c|c|c|c|c|c|c|c|c|}
\hline \multirow{2}{*}{ Effect } & \multicolumn{3}{|c|}{ Conrad } & \multicolumn{3}{|c|}{ Corvallis } & \multicolumn{2}{|c|}{ Kalispell } \\
\hline & 2011 & 2012 & 2013 & 2011 & 2012 & 2013 & 2011 & 2012 \\
\hline $\mathrm{N}$ source & \multicolumn{8}{|c|}{$\mathrm{kg} \mathrm{ha}^{-1}$} \\
\hline Urea & 2488 & $5111^{\mathrm{bE}}$ & 4506 & $3161^{\mathrm{a}}$ & 4640 & 2623 & $3699^{\mathrm{b}}$ & 4506 \\
\hline ESN & 2556 & $5515^{\mathrm{a}}$ & 4439 & $2690^{\mathrm{b}}$ & 4842 & 2488 & $3901^{\mathrm{ab}}$ & 4304 \\
\hline Blend & - & $5447^{\mathrm{ab}}$ & 4708 & $2757^{\mathrm{b}}$ & 4640 & 2152 & $4035^{\mathrm{a}}$ & 4371 \\
\hline Prob $>F$ & 0.969 & 0.051 & 0.117 & $<0.001$ & 0.699 & 0.452 & 0.003 & 0.517 \\
\hline \multicolumn{9}{|c|}{ At-seeding $\mathrm{N}$ rate, $\mathrm{kg} \mathrm{ha}^{-1}$} \\
\hline 0 & 2488 & 4035 & 3699 & 2623 & 3833 & 1816 & 2898 & 3833 \\
\hline Low $^{\dagger}$ & 2556 & 5178 & 4640 & 2757 & 4304 & 2556 & 4237 & 4371 \\
\hline Medium & 2892 & 5447 & 4573 & 2959 & 5044 & 2556 & 4237 & 4371 \\
\hline High & 3161 & 5582 & 4439 & 3026 & 4640 & 2152 & 4102 & 4371 \\
\hline Prob $>F($ trend $)$ & $0.006^{\ddagger}$ & $0.003^{\ddagger}$ & 0.055 & $0.048^{\ddagger}$ & 0.050 & 0.051 & 0.114 & 0.945 \\
\hline \multicolumn{9}{|c|}{ Topdress $\mathrm{N}$ rate, $\mathrm{kg} \mathrm{ha}^{-1}$} \\
\hline 0 & $2389^{\mathrm{bs}}$ & 5380 & 4573 & $2690^{\mathrm{b}}$ & $4506^{\mathrm{b}}$ & 2354 & $3699^{\mathrm{b}}$ & 4371 \\
\hline 45 & $2741^{\mathrm{a}}$ & 5447 & 4506 & $3026^{\mathrm{a}}$ & $4977^{\mathrm{a}}$ & 2488 & $4035^{\mathrm{a}}$ & 4439 \\
\hline Prob $>F$ & $<0.001$ & 0.749 & 0.410 & $<0.001$ & $<0.001$ & 0.813 & 0.003 & 0.175 \\
\hline
\end{tabular}

${ }^{£}$ Down a column for each site-year source means followed by different letter are significant at $p<0.05$.

${ }^{\dagger}$ At-seeding $\mathrm{N}$ rates: low, medium, and high were 56, 112, and $168 \mathrm{~kg} \mathrm{ha}^{-1}$ for Conrad and 112, 224, and $336 \mathrm{~kg} \mathrm{ha}^{-1}$ for Corvallis and Kalispell.

$\ddagger$ represents significant linear trend, for at-seeding $\mathrm{N}$ rate for each site-year.

${ }^{\S}$ Down a column for topdress $\mathrm{N}$ rates, LS means followed by different letters are significant at $p<0.05$ for each source.

urea resulted in $16 \%$ more GY than ESN and blend combined. In 2011, at Kalispell, the blend yielded $336 \mathrm{~kg} \mathrm{ha}^{-1}$ more compared to urea alone (Table 2). Overall, urea-ESN blend resulted in a significantly higher GY at Kalispell.

At-seeding $\mathrm{N}$ rate significantly affected wheat GY at Conrad in 2011 and 2012 and at Corvallis in 2012 (Table 2). Wheat GY increased linearly from 2488 to $3161 \mathrm{~kg} \mathrm{ha}^{-1}$ in 2011 and from $4035 \mathrm{~kg} \mathrm{ha}^{-1}$ to $5582 \mathrm{~kg} \mathrm{ha}^{-1}$ in 2012 at Conrad when at-seeding $\mathrm{N}$ rate increased from 0 to $168 \mathrm{~kg} \mathrm{ha}^{-1}$. Similarly, a linear increase from 2623 to $3026 \mathrm{~kg} \mathrm{ha}^{-1}$ was observed in 2011 at Corvallis when at-seeding $\mathrm{N}$ rate increased from 0 to $336 \mathrm{~kg} \mathrm{ha}^{-1}$ (Table 2). A quadratic trend was observed at Corvallis in 2012 and 2013 where GY reached peak at the medium $\mathrm{N}$ rate $\left(224 \mathrm{~kg} \mathrm{ha}^{-1}\right)$.

The topdress $\mathrm{N}$ treatment significantly affected GY in four of the eight site-years. At Conrad in 2011, Corvallis in 2011 and 2012, and Kalispell 2011, topdressing $45 \mathrm{~kg} \mathrm{~N} \mathrm{ha}^{-1}$ resulted in $14.7,12.5,10.5$, and $9.1 \%$ more GY than those plots that did not receive topdress $\mathrm{N}$ (Table 2 ).

The assessment of interaction effects of source by atseeding $\mathrm{N}$ rate on GY showed significant $(p<0.07)$ effect at Conrad in 2013 and Kalispell in 2011. At Conrad, for $168 \mathrm{~kg} \mathrm{ha}^{-1}$ at-seeding $\mathrm{N}$ rate, the blend source had $621 \mathrm{~kg} \mathrm{ha}^{-1}$ more GY compared with urea and ESN combined. At this site-year, for urea, GY was linearly increased with increase in at-seeding $\mathrm{N}$ rate (Table 3(a)). At Kalispell, for $336 \mathrm{~kg} \mathrm{ha}^{-1}$ at-seeding $\mathrm{N}$ rate, ESN had $563 \mathrm{~kg} \mathrm{ha}^{-1}$ more GY than urea. Consistent with Conrad 2013, at Kalispell in 2011, GY decreased linearly with increase in at-seeding $\mathrm{N}$ rate from $112 \mathrm{~kg} \mathrm{ha}^{-1}$ to $336 \mathrm{~kg} \mathrm{ha}^{-1}$. The source by topdress interaction showed significant differences at Conrad in $2011(p<0.016)$ and $2013(p<0.025)$. In both years at this site, for each source, topdressing $\mathrm{N}$ resulted in more GY than not topdressing although statistically significant LS means difference was observed only for ESN source in 2011 and urea in 2013 (Table 3(a)). At Conrad in 2013, at the $45 \mathrm{~kg} \mathrm{ha}^{-1}$ topdress $\mathrm{N}$ rate, the blend had $448 \mathrm{~kg} \mathrm{ha}^{-1}$ more GY than urea.

Results of assessment of three-way interaction effects $(p<$ 0.15 ) of source and at-seeding and topdress $N$ rates on GY are presented in Table 3(b). At Conrad the maximum GY was obtained with the highest rate $\left(168 \mathrm{~kg} \mathrm{ha}^{-1}\right)$ at-seeding $\mathrm{N}$ rate combined with $45 \mathrm{~kg} \mathrm{ha}^{-1}$ topdress $\mathrm{N}$ for the blend and ESN sources (Table 3(b)). For this site-year, the maximum yield for urea source was achieved with $120 \mathrm{~kg} \mathrm{ha}^{-1}$ at-seeding $\mathrm{N}$ rate without topdress N. In 2013, at Conrad, the lowest at-seeding $\mathrm{N}$ rate combined with $45 \mathrm{~kg} \mathrm{ha}^{-1}$ topdress $\mathrm{N}$ rate maximized yield for the ESN and urea. In contrast, GY was maximized with the application of $168 \mathrm{~N} \mathrm{ha}^{-1}$ at-seeding $\mathrm{N}$ rate for the blend source although the values were not statistically different from other rates but the lowest at-seeding rate without topdress. At Kalispell in 2011, similar trend was observed for the ESN and urea where GY was maximized with the low $\left(112 \mathrm{~kg} \mathrm{ha}^{-1}\right)$ at-seeding rate plus $45 \mathrm{~kg} \mathrm{~N} \mathrm{ha}^{-1}$ topdress rate. Furthermore, at Kalispell in 2011, GY was maximized with the application of $224 \mathrm{~kg} \mathrm{ha}^{-1}$ at-seeding $\mathrm{N}$ rate and $45 \mathrm{~kg} \mathrm{ha}^{-1}$ topdress $\mathrm{N}$ rate combination. But the value was not statistically different from the rest of the rates, except for the low rate without topdress $\mathrm{N}$. Results suggest that low to medium at-seeding $\mathrm{N}$ rate along topdres $\mathrm{N}$ rate improved GY. In Montana, despite the short spring wheat growing season, yields did increase in this study as a result of topdressing. Splitting N improved yield but this may not translate to positive marginal 
TABLE 3: (a) Simple effects of two-way interactions of source by at-seeding and topdress $\mathrm{N}$ rates for grain yield in selected site-years where interaction effect was significant at least at $p<0.1$. (b) Simple effects of three-way interactions of source and at-seeding and topdress $\mathrm{N}$ rates on grain yield in selected site-years where interaction effect was significant at least at $p<0.15$.

(a)

\begin{tabular}{|c|c|c|c|c|}
\hline Site-year & At-seeding $\mathrm{N}$ rate, $\mathrm{kg} \mathrm{ha}^{-1}$ & Blend & ESN & Urea \\
\hline & & $\mathrm{kgh}$ & & \\
\hline \multirow{4}{*}{ Conrad-2013 } & 56 & 4536 & 4578 & 4855 \\
\hline & 112 & 4695 & 4570 & 4452 \\
\hline & 168 & $4838^{\mathrm{A} \dagger}$ & $4200^{\mathrm{B}}$ & $4234^{\mathrm{B}}$ \\
\hline & Prob $>F($ trend $)$ & 0.156 & 0.754 & $0.019^{\ddagger}$ \\
\hline \multirow{4}{*}{ Kalispell-2011 } & 112 & 3656 & 4013 & 3785 \\
\hline & 224 & 3878 & 3875 & 3603 \\
\hline & 336 & $3749^{\mathrm{AB}}$ & $3905^{\mathrm{A}}$ & $3342^{\mathrm{B}}$ \\
\hline & Prob $>F($ trend $)$ & 0.745 & 0.689 & $0.05^{\ddagger}$ \\
\hline & \multicolumn{4}{|c|}{ Topdress $\mathrm{N}$ rate, $\mathrm{kg} \mathrm{ha}^{-1}$} \\
\hline \multirow{2}{*}{ Conrad-2011 } & 0 & 2445 & $2255^{\mathrm{b} \S}$ & 2470 \\
\hline & 45 & 2668 & $2943^{\mathrm{a}}$ & 2613 \\
\hline \multirow{2}{*}{ Conrad-2013 } & 0 & 4648 & 4379 & $4743^{\mathrm{a}}$ \\
\hline & 45 & $4732^{\mathrm{A}}$ & $4519^{\mathrm{AB}}$ & $4284^{\mathrm{Bb}}$ \\
\hline
\end{tabular}

${ }^{\dagger}$ Across rows for each site-year and at-seeding N rate, LS means followed by different letters are significant at $p<0.05$.

${ }^{\ddagger}$ Significant linear trend for at-seeding $\mathrm{N}$ rate for each source.

${ }^{\S}$ Down a column for topdress $\mathrm{N}$ rates, LS means followed by different letters are significant at $p<0.05$ for each source.

(b)

\begin{tabular}{|c|c|c|c|c|c|c|}
\hline At-seeding-topdress $\mathrm{N}$ rate, $\mathrm{kg} \mathrm{ha}^{-1}$ & Blend & ESN & Urea & Blend & ESN & Urea \\
\hline & \multicolumn{3}{|c|}{ Conrad-2011 } & \multicolumn{3}{|c|}{ Conrad-2013 } \\
\hline $56-0$ & $2523^{\text {bcs }}$ & $1812^{\mathrm{c}}$ & $2027^{\mathrm{b}}$ & $4385^{\mathrm{b}}$ & $4301^{\mathrm{ab}}$ & $4755^{\mathrm{a}}$ \\
\hline $56-45$ & $2202^{c}$ & $2268^{c}$ & $2298^{\mathrm{b}}$ & $4688^{\mathrm{ab}}$ & $4855^{\mathrm{a}}$ & $4956^{\mathrm{a}}$ \\
\hline $112-0$ & $2008^{\mathrm{cB} \dagger}$ & $2480^{\mathrm{bcB}}$ & $2932^{\mathrm{aA}}$ & $4620^{\mathrm{ab}}$ & $4486^{\mathrm{ab}}$ & $4805^{\mathrm{a}}$ \\
\hline $112-45$ & $2454^{\mathrm{bc}}$ & $2886^{\mathrm{b}}$ & $2885^{\mathrm{a}}$ & $4771^{\mathrm{abA}}$ & $4654^{\mathrm{abA}}$ & $4099^{\mathrm{bB}}$ \\
\hline $168 / 0$ & $2804^{\mathrm{ab}}$ & $2474^{\mathrm{bc}}$ & $2450^{\mathrm{ab}}$ & $4939^{\mathrm{aA}}$ & $4351^{\mathrm{abB}}$ & $4670^{\mathrm{abAB}}$ \\
\hline $168-45$ & $3349^{\mathrm{aAB}}$ & $3676^{\mathrm{aA}}$ & $2656^{\mathrm{abB}}$ & $4738^{\mathrm{abA}}$ & $4049^{\mathrm{bB}}$ & $3797^{\mathrm{bB}}$ \\
\hline \multicolumn{7}{|c|}{ Kalispell-2011 } \\
\hline $112-0$ & $3478^{b}$ & $3808^{\mathrm{b}}$ & $3681^{\mathrm{ab}}$ & & & \\
\hline $112-45$ & $3833^{\mathrm{ab}}$ & $4218^{\mathrm{a}}$ & $3889^{a}$ & & & \\
\hline $224-0$ & $3842^{\mathrm{ab}}$ & $3755^{\mathrm{b}}$ & $3583^{\mathrm{ab}}$ & & & \\
\hline $224-45$ & $3915^{\mathrm{a}}$ & $3994^{\mathrm{ab}}$ & $3624^{\mathrm{ab}}$ & & & \\
\hline $336-0$ & $3625^{\mathrm{abAB}}$ & $3901^{\mathrm{abA}}$ & $3431^{\mathrm{bB}}$ & & & \\
\hline $336-45$ & $3872^{\mathrm{aA}}$ & $3910^{\mathrm{abA}}$ & $3253^{\mathrm{bB}}$ & & & \\
\hline
\end{tabular}

\footnotetext{
${ }^{\$}$ Down a column for each source, at-seeding-topdress N rate LS means followed by different lowercase letters are significant at $p<0.05$.

${ }^{\dagger}$ Across rows for each site-year, at-seeding-topdress $\mathrm{N}$ rate combination, source LS means followed by different uppercase letters are significant at $p<$ 0.05 .
}

return. We have found conflicting results from the different site-years regarding the effect of sources and $\mathrm{N}$ rates.

3.2. Grain Protein Content. In 2011, GP content values ranged from 13.9 to $15.6 \%$ at Corvallis, 11.2 to $13.8 \%$ at Kalispell, and 9.1 to $9.9 \%$ at Conrad. In 2012, excellent GP values were achieved at Kalispell (from 12.8 to $14.6 \%$ ) and Corvallis (from 12.7 to $13.4 \%$ ). At Conrad, the GP content was also high, ranging from 9.6 to $13.6 \%$. Grain protein ranged from 14.7 to $17.3 \%$ at Corvallis and 11.0 to $14.4 \%$ at Conrad in 2013.
Grain protein content was significantly affected by $\mathrm{N}$ sources at Conrad in all the three years and at Kalispell in 2012 only (Table 4). At Conrad in 2011, the ESN and blend sources combined had $0.6 \%$ higher GP content than urea. Likewise, in 2013, the ESN source had $0.5 \%$ more GP content than the urea source. In contrast, in 2012 at Conrad, urea had 0.9 and $0.4 \%$ more GP content than ESN and blend, respectively. At Kalispell in 2012, the ESN and blend sources combined had $0.50 \%$ more GP content than urea. Wheat GP has increased with increase in at-seeding $\mathrm{N}$ rates at all site-years except at Corvallis in 2012. Accordingly, wheat GP values increased 
TABLE 4: Effect of at $\mathrm{N}$ source and preplant and topdress $\mathrm{N}$ rate on spring wheat grain protein Conrad, Corvallis and Kalispell, 2011-2013 growing seasons.

\begin{tabular}{|c|c|c|c|c|c|c|c|c|}
\hline \multirow{2}{*}{ Effect } & \multicolumn{3}{|c|}{ Conrad } & \multicolumn{3}{|c|}{ Corvallis } & \multicolumn{2}{|c|}{ Kalispell } \\
\hline & 2011 & 2012 & 2013 & 2011 & 2012 & 2013 & 2011 & 2012 \\
\hline N source, $\mathrm{kg} \mathrm{ha}^{-1}$ & \multicolumn{8}{|c|}{$\%$} \\
\hline Urea & $9.4^{\mathrm{b} £}$ & $12.9^{\mathrm{a}}$ & $13.6^{\mathrm{b}}$ & 14.8 & 13.4 & 16.7 & 12.6 & $13.8^{\mathrm{b}}$ \\
\hline ESN & $10.0^{\mathrm{a}}$ & $12.0^{\mathrm{c}}$ & $14.1^{\mathrm{a}}$ & 14.9 & 12.9 & 16.8 & 12.4 & $14.2^{\mathrm{a}}$ \\
\hline Blend & $9.9^{\mathrm{a}}$ & $12.5^{\mathrm{b}}$ & $13.8^{\mathrm{ab}}$ & 14.9 & 12.7 & 16.8 & 12.4 & $14.4^{\mathrm{a}}$ \\
\hline Prob $>F$ & 0.0501 & $<0.001$ & 0.011 & 0.732 & 0.123 & 0.887 & 0.656 & $<0.001$ \\
\hline \multicolumn{9}{|c|}{ At-seeding $\mathrm{N}$ rate, $\mathrm{kg} \mathrm{ha}^{-1}$} \\
\hline 0 & 9.1 & 9.6 & 11.0 & 13.9 & 13.1 & 14.7 & 11.2 & 12.8 \\
\hline Low $^{\dagger}$ & 9.1 & 11.1 & 13.0 & 14.4 & 12.7 & 16.4 & 11.7 & 13.9 \\
\hline Medium & 9.3 & 12.7 & 14.1 & 15.6 & 13.4 & 16.6 & 13.1 & 13.9 \\
\hline High & 9.9 & 13.6 & 14.4 & 15.6 & 13.0 & 17.3 & 13.8 & 14.6 \\
\hline Prob $>F($ trend $)$ & $0.013^{\ddagger}$ & $<0.001^{\ddagger}$ & $<0.001^{\ddagger}$ & $<0.001^{\ddagger}$ & 0.078 & $0.003^{\ddagger}$ & $<0.001^{\ddagger}$ & $<0.001^{\ddagger}$ \\
\hline \multicolumn{9}{|c|}{ Topdress $\mathrm{N}$ rate, $\mathrm{kg} \mathrm{ha}^{-1}$} \\
\hline 0 & 9.4 & $12.1^{\mathrm{bs}}$ & $13.6^{\mathrm{b}}$ & $14.4^{\mathrm{b}}$ & 13.0 & 16.9 & $12.1^{\mathrm{b}}$ & $14.4^{\mathrm{b}}$ \\
\hline 45 & 9.5 & $12.9^{\mathrm{a}}$ & $14.1^{\mathrm{a}}$ & $15.3^{\mathrm{a}}$ & 13.0 & 16.6 & $12.9^{\mathrm{a}}$ & $13.9^{\mathrm{a}}$ \\
\hline Prob $>F$ & 0.918 & 0.001 & 0.001 & 0.001 & 0.968 & 0.251 & 0.001 & 0.001 \\
\hline
\end{tabular}

${ }^{£}$ Down a column for each site-year source means followed by different letter are significant at $p<0.05$.

${ }^{\dagger}$ At-seeding $\mathrm{N}$ rates: low, medium, and high were 56,112 , and $168 \mathrm{~kg} \mathrm{ha}^{-1}$ for Conrad and 112, 224, and $336 \mathrm{~kg} \mathrm{ha}^{-1}$ for Corvallis and Kalispell.

${ }^{\ddagger}$ Significant linear trend, for at-seeding $\mathrm{N}$ rate for each site-year.

${ }^{\S}$ Down a column for topdress $\mathrm{N}$ rates, LS means followed by different letters are significant at $p<0.05$ for each source.

linearly with increase in at-seeding $\mathrm{N}$ rate for all site-years where effects were significant (Table 4).

Source by at-seeding $\mathrm{N}$ rate interaction was significant at Conrad $(p<0.02)$ and Kalispell $(p<0.001)$ in 2012. At Conrad GP content increased consistently with increase in at-seeding $\mathrm{N}$ rate from $56 \mathrm{~kg} \mathrm{ha}^{-1}$ to $168 \mathrm{~kg} \mathrm{ha}^{-1}$ for all the three sources. However, a more steep increase was observed for urea than ESN or the blend (Table 5). At Conrad in 2012, at $1056 \mathrm{~kg} \mathrm{ha}^{-1}$ at-seeding $\mathrm{N}$ rate, all sources exhibited low and insignificant GP content (11.1 to $11.2 \%$ ). At the $112 \mathrm{~kg} \mathrm{ha}^{-1}$ atseeding $\mathrm{N}$ rate, GP content for blend and ESN was 1.2 and $0.7 \%$ lower than urea, respectively, while the difference was 1.4 and $0.6 \%$ for $168 \mathrm{~kg} \mathrm{ha}^{-1}$ at-seeding $\mathrm{N}$ rate, in the same order.

At Kalispell in 2012, GP content linearly increased with at-seeding $\mathrm{N}$ rates for urea but decreased with increasing atseeding $\mathrm{N}$ rate from $112 \mathrm{~kg} \mathrm{ha}^{-1} \mathrm{t}$ to $224 \mathrm{~kg} \mathrm{ha}^{-1}$ and then peaked again with the ESN and blend sources (Table 5). For this site-year, at the $112 \mathrm{~kg} \mathrm{ha}^{-1}$ at-seeding $\mathrm{N}$ rate, urea had the lowest GP content while ESN and the blend had similar GP content (Table 5).

Source by topdress $\mathrm{N}$ interaction was significant at Conrad in $2012(p<0.05)$, at Corvallis in all the three years $(p<0.02$ to $p<0.06)$, and at Kalispell in $2012(p<0.001)$. At Conrad in 2012, without topdress N, ESN and urea combined resulted in $0.7 \%$ more GP content than the blend. With topdress $\mathrm{N}$, urea resulted in 1.1 and $0.7 \%$ more GP content than the blend and ESN, respectively (Table 5). Additionally, at this site-year, topdress $\mathrm{N}$ resulted in $0.8,0.6$, and $1.1 \%$ more GP content for the blend, ESN, and urea, respectively, than plots that did not receive topdress $\mathrm{N}$.
At Corvallis in 2011, with topdress N, the blend source had $0.5 \%$ more GP content than urea. Likewise, at this siteyear, consistent across sources, topdressing $\mathrm{N}$ resulted in more GP content than no topdressing. Accordingly, topdress $\mathrm{N}$ resulted in $1.2,1.2$, and $0.6 \%$ more GP content for the blend, ESN, and urea sources, respectively, compared with no topdress.

At Corvallis in 2012, the effect of sources on the GP content at each topdress $\mathrm{N}$ was inconsistent. For this site-year, both blend and urea resulted in $0.6 \%$ more GP content than the ESN source with no topdress $\mathrm{N}$ while urea resulted in almost 1\% more GP content than blend and ESN combined. For this site-year, for the blend source topdressed plots resulted in $0.7 \%$ less GP content than nontopdressed plots; however, when wheat was topdressed with $\mathrm{N}, 0.5 \%$ more GP content was obtained compared to nontopdressed plots (Table 5).

At Corvallis in 2013, without topdress N, urea had $0.8 \%$ less GP content than ESN and blend sources combined whereas, with topdress N, ESN and urea sources resulted in $0.7 \%$ more GP content than the blend (Table 5). For this siteyear, topdress $\mathrm{N}$ resulted in $0.8 \%$ less and $0.6 \%$ more GP content for blend and urea sources, respectively.

At Kalispell in 2012, without topdress N, blend and ESN sources resulted in 1.2 and $1.0 \%$ more GP content than urea, respectively. Furthermore, for this site-year, when sources were blend and ESN, topdressed plots had 0.8 and $0.7 \%$ more GP content than plots that did not receive topdress $\mathrm{N}$.

3.3. Nitrogen Uptake. Nitrogen source significantly affected GNU only at Corvallis and Kalispell in 2011 (Table 6). At 
TABLE 5: Simple effects of two-way interactions of source by atseeding and topdress $\mathrm{N}$ rates for wheat grin protein from selected site-years where interaction effect was significant at least at $p<0.1$.

\begin{tabular}{|c|c|c|c|c|}
\hline \multirow{2}{*}{ Site-year } & \multirow{2}{*}{$\begin{array}{l}\text { At-seeding } \mathrm{N} \\
\text { rate, } \mathrm{kg} \mathrm{ha}^{-1}\end{array}$} & \multicolumn{3}{|c|}{ Source } \\
\hline & & Blend & ESN & Urea \\
\hline \multirow{5}{*}{ Conrad-2012 } & & $\%$ & & \\
\hline & 56 & 11.1 & 11.1 & 11.2 \\
\hline & 112 & $12.1^{\mathrm{C} \dagger}$ & $12.6^{\mathrm{B}}$ & $13.3^{\mathrm{B}}$ \\
\hline & 168 & $12.9^{\mathrm{C}}$ & $13.7^{\mathrm{B}}$ & $14.3^{\mathrm{A}}$ \\
\hline & $\begin{array}{l}\text { Prob }>F \\
\text { (trend) }\end{array}$ & $0.012^{\ddagger}$ & $0.021^{\ddagger}$ & $0.011^{\ddagger}$ \\
\hline \multirow{4}{*}{$\begin{array}{l}\text { Kalispell- } \\
2012\end{array}$} & 112 & $14.4^{\mathrm{A}}$ & $14.3^{\mathrm{A}}$ & $13.0^{\mathrm{B}}$ \\
\hline & 224 & 13.7 & 14.2 & 13.9 \\
\hline & 336 & 14.5 & 14.8 & 14.5 \\
\hline & $\begin{array}{l}\text { Prob }>F \\
\text { (trend) }\end{array}$ & $0.023^{€}$ & $0.047^{€}$ & $0.009^{\ddagger}$ \\
\hline & $\begin{array}{c}\text { Topdress N, } \\
\mathrm{kg} \mathrm{ha}^{-1}\end{array}$ & & & \\
\hline \multirow{2}{*}{ Conrad-2012 } & 0 & $11.6^{\mathrm{Bb} \varsigma}$ & $12.2^{\mathrm{Ab}}$ & $12.4^{\mathrm{Ab}}$ \\
\hline & 45 & $12.4^{\mathrm{Ba}}$ & $12.8^{\mathrm{Ba}}$ & $13.5^{\mathrm{Aa}}$ \\
\hline \multirow{2}{*}{$\begin{array}{l}\text { Corvallis- } \\
2011\end{array}$} & 0 & $14.7^{\mathrm{b}}$ & $14.6^{\mathrm{b}}$ & $14.8^{\mathrm{b}}$ \\
\hline & 45 & $15.9^{\mathrm{Aa}}$ & $15.8^{\mathrm{ABa}}$ & $15.4^{\mathrm{Ba}}$ \\
\hline \multirow{2}{*}{$\begin{array}{l}\text { Corvallis- } \\
2012\end{array}$} & 0 & $13.2^{\mathrm{Aa}}$ & $12.6^{\mathrm{B}}$ & $13.2^{\mathrm{Ab}}$ \\
\hline & 45 & $12.5^{\mathrm{Bb}}$ & $12.8^{\mathrm{B}}$ & $13.7^{\mathrm{Aa}}$ \\
\hline \multirow{2}{*}{$\begin{array}{l}\text { Corvallis- } \\
2013\end{array}$} & 0 & $17.2^{\mathrm{Aa}}$ & $17.1^{\mathrm{A}}$ & $16.4^{\mathrm{Bb}}$ \\
\hline & 45 & $16.4^{\mathrm{Bb}}$ & $17.1^{\mathrm{A}}$ & $17^{\mathrm{Aa}}$ \\
\hline \multirow{2}{*}{$\begin{array}{l}\text { Kalispell- } \\
2012\end{array}$} & 0 & $14.6^{\mathrm{Aa}}$ & $14.8^{\mathrm{Aa}}$ & $13.8^{\mathrm{B}}$ \\
\hline & 45 & $13.8^{\mathrm{b}}$ & $14.1^{\mathrm{b}}$ & 13.8 \\
\hline
\end{tabular}

${ }^{\dagger}$ Across rows for each site-year, at-seeding $\mathrm{N}$ rate, or topdress $\mathrm{N}$ rate, LS means followed by different uppercase letters are significant at $p<0.05$.

$\ddagger \& €$ represent significant linear and quadratic trends, for at-seeding $\mathrm{N}$ rate for each source.

${ }^{\S}$ Down a column for topdress $\mathrm{N}$ rates, LS means followed by different lowercase letters are significant at $p<0.05$ for each source.

Corvallis, urea resulted in $16.3 \mathrm{~kg} \mathrm{ha}^{-1}$ more GNU than ESN and blend combined. In contrast, ESN had $7.8 \mathrm{~kg} \mathrm{ha}^{-1}$ more GNU than urea at Kalispell in 2011.

At-seeding $\mathrm{N}$ rate treatments significantly affected GNU at all site-years except at Corvallis 2013 (Table 6). Grain N uptake increased linearly with increase in at-seeding $\mathrm{N}$ rate at all site-years where the effect was significant except at Corvallis 2012. At Corvallis in 2012, a quadratic trend was observed where GNU peaked at $224 \mathrm{~kg} \mathrm{ha}^{-1}$ at-seeding $\mathrm{N}$ rate. Likewise, plots supplemented with topdress $\mathrm{N}$ resulted in higher GNU than nontopdressed plots consistently across site-years where the effect was significant (Table 6).

Source by at-seeding $\mathrm{N}$ rate interaction was significant at Conrad in $2011(p<0.05)$ and $2013(0.021)$ and at Kalispell $(p<0.021)$ in 2011. At Conrad GNU increased linearly with increase in at-seeding $\mathrm{N}$ rate for blend and ESN. In contrast, GNU was increased to $41.5 \mathrm{~kg} \mathrm{ha}^{-1}$ at $112 \mathrm{~kg} \mathrm{ha}^{-1}$ at-seeding $\mathrm{N}$ rate and decreased to $37.3 \mathrm{~kg} \mathrm{ha}^{-1}$ with $168 \mathrm{~kg} \mathrm{Nha}^{-1}$ atseeding $\mathrm{N}$ rate for urea source (Table 7 ). Additionally, at the
112 and $168 \mathrm{~kg} \mathrm{ha}^{-1}$ at-seeding $\mathrm{N}$ rates, sources showed significantly different response. Accordingly, at $112 \mathrm{~kg} \mathrm{ha}^{-1}$ atseeding $\mathrm{N}$ rate, blend had 8.5 and 8.8 less GNU than ESN and urea, respectively. In contrast, at $168 \mathrm{~kg} \mathrm{ha}^{-1}$ at-seeding $\mathrm{N}$ rate, blend and ESN had 12.4 and 10.3 more GNU than urea, respectively (Table 7).

At Conrad in 2013, for the blend source, GNU increased linearly with increase in at-seeding $\mathrm{N}$ rate. At this siteyear, at $168 \mathrm{~kg} \mathrm{ha}^{-1}$ at-seeding $\mathrm{N}$ rate, the blend source had $10.6 \mathrm{~kg} \mathrm{ha}^{-1}$ more GNU than ESN and urea combined. At Kalispell in 2011, GNU increased linearly with at-seeding $\mathrm{N}$ rate from 64.0 to $81.5 \mathrm{~kg} \mathrm{ha}^{-1}$ when at-seeding $\mathrm{N}$ rate increased from 112 to $336 \mathrm{~kg} \mathrm{ha}^{-1}$ for the blend source. At this site-year, at $112 \mathrm{~kg} \mathrm{ha}^{-1}$ at-seeding $\mathrm{N}$ rate, ESN had $10.1 \mathrm{~kg} \mathrm{ha}^{-1}$ more GNU than ESN. At $336 \mathrm{~kg} \mathrm{ha}^{-1}$ at-seeding $\mathrm{N}$ rate, blend and ESN had 11.0 and $8.7 \mathrm{~kg} \mathrm{ha}^{-1}$ more GNU than urea.

Significant source by topdress $\mathrm{N}$ rate interaction was observed only at Conrad in 2013. Accordingly, topdressing $\mathrm{N}$ increased GNU by 6.5 and $6.2 \mathrm{~kg} \mathrm{ha}^{-1}$ compared with no topdressing. Alternatively, for urea GNU was decreased by $8.4 \mathrm{~kg} \mathrm{ha}^{-1}$ in plots that received topdress $\mathrm{N}$ compared with that not receiving $\mathrm{N}$.

3.4. Partial Budget Economic Analysis. Only three site-years, Conrad and Corvallis in 2012 and Kalispell in 2011, were considered for the economic analysis based on significant differences in GY (Table 8(a)). Net returns for GP-unadjusted revenue were higher for the blend source at Conrad in 2012 (Table 8(a)).

A slight revenue advantage was obtained with the blend at Kalispell. At Corvallis, urea outperformed both the ESN and blend. In fact, ESN performed poorly in all the three site-ears. At Conrad in 2012, ESN had lower marginal net return than blend ( $\$ 19.02 \mathrm{ha}^{-1}$ more). At Kalispell, a similar result was observed where the blend resulted in $\$ 8.29 \mathrm{ha}^{-1}$ additional income compared to urea. At Conrad, MRR was \$1.02 and 1.56 for ESN and blend, respectively, while at Kalispell the MRR was 0.38 and 1.17 for GP-unadjusted revenue. At Corvallis 2012, negative marginal rate of return was observed for both ESN and blend sources.

Similarly, protein-unadjusted and -adjusted partial budget analysis comparing medium at-seeding rate and low atseeding rate along $45 \mathrm{~kg} \mathrm{ha}^{-1}$ topdress $\mathrm{N}$ rates showed that ESN did not result in better marginal profit or marginal rate of return compared with urea at the specified rates (Table $8(b)$ ).

\section{Discussion and Conclusion}

This study has enabled us to evaluate the $\mathrm{N}$ source effect on GY and GP in a wide range of growing environments. Average spring wheat GY has varied from 1816 to $5583 \mathrm{~kg} \mathrm{ha}^{-1}$ (Table 2) and GP content ranged from 9.1 to $17.3 \%$ among the site-years (Table 4).

Spring wheat GY responded to $\mathrm{N}$ applied at the time of seeding at seven of eight site-years (Table 2); also higher GP content was achieved with at-seeding $\mathrm{N}$ application (Table 4). These results emphasize the importance of initial $\mathrm{N}$ fertilizer 
TABLE 6: Effect of at N source, preplant and topdress N rate on spring wheat grain uptake Conrad, Corvallis and Kalispell, 2011-2013 growing seasons.

\begin{tabular}{|c|c|c|c|c|c|c|c|c|}
\hline \multirow{2}{*}{ Effect } & \multicolumn{3}{|c|}{ Conrad } & \multicolumn{3}{|c|}{ Corvallis } & \multicolumn{2}{|c|}{ Kalispell } \\
\hline & 2011 & 2012 & 2013 & 2011 & 2012 & 2013 & 2011 & 2012 \\
\hline $\mathrm{N}$ source & \multicolumn{8}{|c|}{$\mathrm{kg} \mathrm{ha}^{-1}$} \\
\hline Urea & 51.6 & 117.7 & 106.5 & $96.4^{\mathrm{a} £}$ & 106.5 & 72.9 & $99.8^{\mathrm{b}}$ & 106.5 \\
\hline ESN & 54.9 & 114.3 & 107.6 & $78.5^{\mathrm{b}}$ & 107.6 & 71.7 & $104.3^{\mathrm{ab}}$ & 105.4 \\
\hline Blend & 54.9 & 116.6 & 109.9 & $81.8^{\mathrm{b}}$ & 102.0 & 67.3 & $107.6^{\mathrm{a}}$ & 107.6 \\
\hline Prob $>F$ & 0.620 & 0.328 & 0.401 & $<0.001$ & 0.664 & 0.853 & 0.011 & 0.782 \\
\hline \multicolumn{9}{|c|}{ At-seeding $\mathrm{N}$ rate } \\
\hline 0 & 44.8 & 86.3 & 68.4 & 65.0 & 86.3 & 46.0 & 53.8 & 85.2 \\
\hline Low $^{\dagger}$ & 43.7 & 98.7 & 104.3 & 77.4 & 94.2 & 71.7 & 96.4 & 104.3 \\
\hline Medium & 53.8 & 118.8 & 111.0 & 88.6 & 116.6 & 77.4 & 106.5 & 104.3 \\
\hline High & 62.8 & 131.2 & 108.7 & 91.9 & 105.4 & 62.8 & 108.7 & 109.9 \\
\hline Prob $>F$ & $<0.001^{\ddagger}$ & $<0.001^{\ddagger}$ & $0.047^{\ddagger}$ & $0.001^{\ddagger}$ & $0.008^{€}$ & 0.395 & $<0.001^{\ddagger}$ & $0.051^{\ddagger}$ \\
\hline \multicolumn{9}{|c|}{ Topdress N rate } \\
\hline 0 & $50.5^{\mathrm{bs}}$ & $112.1^{\mathrm{b}}$ & 106.5 & $79.6^{\mathrm{b}}$ & 99.8 & 70.62 & $98.7^{\mathrm{b}}$ & 107.6 \\
\hline 45 & $57.2^{\mathrm{a}}$ & $120.0^{\mathrm{a}}$ & 108.7 & $91.9^{\mathrm{a}}$ & 111.0 & 70.6 & $109.9^{\mathrm{a}}$ & 105.4 \\
\hline Prob $>F$ & 0.049 & $<0.001$ & 0.321 & $<0.001$ & $<0.001$ & 0.932 & 0.001 & 0.204 \\
\hline
\end{tabular}

${ }^{E}$ Down a column for each site-year source means followed by different letter are significant at $p<0.05$.

${ }^{\dagger}$ At-seeding N rates: low, medium, and high were 56,112, and $168 \mathrm{~kg} \mathrm{ha}^{-1}$ for Conrad and 112, 224, and $336 \mathrm{~kg} \mathrm{ha}^{-1}$ for Corvallis and Kalispell.

₹ \& € represent significant linear and quadratic trends, for at-seeding $\mathrm{N}$ rate for each site-year.

${ }^{\S}$ Down a column for topdress $\mathrm{N}$ rates, LS means followed by different letters are significant at $p<0.05$ for each source.

TABLE 7: Simple effects of two-way interactions of source by atseeding and topdress $\mathrm{N}$ rates for $\mathrm{N}$ uptake from selected site-years where interaction effect was significant at least at $p<0.1$.

\begin{tabular}{|c|c|c|c|c|}
\hline \multirow{2}{*}{ Site-year } & \multirow{2}{*}{$\begin{array}{l}\text { At-seeding } \mathrm{N} \\
\text { rate, } \mathrm{kg} \mathrm{ha}^{-1}\end{array}$} & \multicolumn{3}{|c|}{ Source } \\
\hline & & Blend & ESN & Urea \\
\hline \multirow{5}{*}{ Conrad-2011 } & & $\mathrm{kgha}^{-1}$ & & \\
\hline & 56 & 34.6 & 29.4 & 30.3 \\
\hline & 112 & $32.7^{\mathrm{B} \dagger}$ & $41.2^{\mathrm{A}}$ & 41.5 \\
\hline & 168 & $49.7^{\mathrm{A}}$ & $47.6^{\mathrm{AB}}$ & $37.3^{\mathrm{B}}$ \\
\hline & Prob $>F$ (trend) & $0.05^{\ddagger}$ & $0.008^{\ddagger}$ & $0.045^{€}$ \\
\hline \multirow{4}{*}{ Conrad-2013 } & 56 & 89.5 & 94 & 95.2 \\
\hline & 112 & $100.1^{\mathrm{A}}$ & $100.7^{\mathrm{B}}$ & $96.5^{\mathrm{B}}$ \\
\hline & 168 & $104.8^{\mathrm{B}}$ & $93.9^{\mathrm{A}}$ & $94.5^{\mathrm{AB}}$ \\
\hline & Prob $>F($ trend $)$ & $0.022^{\ddagger}$ & 0.165 & 0.754 \\
\hline \multirow{5}{*}{ Kalispell-2011 } & 112 & $64^{\mathrm{A}}$ & $74.1^{\mathrm{AB}}$ & $68.7^{\mathrm{B}}$ \\
\hline & 224 & 77.7 & 77.1 & 73.5 \\
\hline & 336 & $81.5^{\mathrm{A}}$ & $80.2^{\mathrm{A}}$ & $71.5^{\mathrm{B}}$ \\
\hline & Prob $>F$ (trend) & $0.007^{\ddagger}$ & $0.068^{\ddagger}$ & 0.171 \\
\hline & $\begin{array}{l}\text { Topdress N, } \\
\mathrm{kg} \mathrm{ha}^{-1 \S}\end{array}$ & & & \\
\hline \multirow{2}{*}{ Conrad-2013 } & 0 & $94.9^{\mathrm{b}}$ & $93.1^{\mathrm{b}}$ & $99.1^{\mathrm{a}}$ \\
\hline & 45 & $101.4^{\mathrm{Aa}}$ & $99.3^{\mathrm{Aa}}$ & $90.7^{\mathrm{Bb}}$ \\
\hline
\end{tabular}

${ }^{\dagger}$ Across rows for each site-year, at-seeding $\mathrm{N}$ rate, or topdress $\mathrm{N}$ rate, LS means followed by different uppercase letters are significant at $p<0.05$. $¥$ represents significant linear trend, for at-seeding $\mathrm{N}$ rate for each site-year. ${ }^{\S}$ Down a column for topdress $\mathrm{N}$ rates, LS means followed by different lowercase letters are significant at $p<0.05$ for each source. application for wheat stand establishment and early-season crop development. The fact that only three out of eight siteyears have benefited from the application of a high $\mathrm{N}$ rate at seeding suggests that the current university guidelines for spring wheat are too high for the typically observed GYs for the area. This is further reinforced by the finding that GY had not responded to at-seeding $\mathrm{N}$ application rate above the lowest rate at four out of eight site-years (Table 2). Furthermore, in four of eight site-years, GY was significantly increased with topdress $\mathrm{N}$ application (Table 2). Current work is underway at Montana State University to revise $\mathrm{N}$ fertilizer recommendations and adjust them to newly released varieties.

The $45 \mathrm{~kg} \mathrm{Nha}^{-1}$ rate of topdress used in this study is a typically recommended rate for spring wheat grown in Montana for growers aiming to enhance GP values. The GP content was increased with topdress application of $\mathrm{N}$ in five of eight site-years (Table 4). This shows the significance of topdressing $\mathrm{N}$ to boost GP content that essentially improves wheat quality.

No consistent trend in GY associated with $\mathrm{N}$ source was observed in this study: out of eight site-years, urea resulted in higher GYs at three site-years, ESN produced higher GYs at three site-years, and the blend produced higher GYs at two site-years (with 1 site-year having no data available for the blend) (Table 2). These results are in agreement with previous findings $[46,47]$ who observed that ESN and blend have outperformed urea in some years but resulted in lower crop GY in other years.

No significant differences in GP content associated with $\mathrm{N}$ source were observed in most site-years; ESN and blend resulted in higher GP content compared to urea alone at three 
TABLE 8: (a) Protein-unadjusted and -adjusted revenues and marginal returns for selected site-years where grain yield was significant. (b) Protein-unadjusted and -adjusted partial budget analysis comparing medium at-seeding rate (112 and $224 \mathrm{~N} \mathrm{~kg} \mathrm{ha}^{-1}$ at Conrad and Kalispell, resp.) and low at-seeding rate (56 and $112 \mathrm{~kg} \mathrm{ha}^{-1}$ at Conrad and Kalispell, resp.) along $45 \mathrm{~kg} \mathrm{ha}^{-1}$ topdress $\mathrm{N}$ rates for selected site-years.

(a)

\begin{tabular}{|c|c|c|c|c|c|c|}
\hline \multirow{2}{*}{ Site-year } & \multicolumn{3}{|c|}{ Unadjusted for protein } & \multicolumn{3}{|c|}{ Adjusted for protein } \\
\hline & Urea & ESN & Blend & Urea & ESN & Blend \\
\hline & \multicolumn{6}{|c|}{ Net return, $\$ \mathrm{ha}^{-1}$} \\
\hline Conrad-2012 & 648.79 & 650.27 & 669.31 & 536.35 & 448.05 & 529.48 \\
\hline Corvallis-2012 & 243.93 & 74.26 & 126.42 & 209.16 & 15.08 & 55.68 \\
\hline \multirow[t]{2}{*}{ Kalispell-2011 } & 335.39 & 280.13 & 343.68 & 240.45 & 165.70 & 225.31 \\
\hline & \multicolumn{6}{|c|}{ Marginal profit, $\$ \mathrm{ha}^{-1}$} \\
\hline Conrad-2012 & - & 1.48 & 20.50 & - & -88.30 & -6.85 \\
\hline Corvallis-2012 & - & -169.67 & -117.51 & - & -194.08 & -153.50 \\
\hline \multirow[t]{2}{*}{ Kalispell-2011 } & - & -55.26 & 8.29 & - & -74.75 & -15.13 \\
\hline & \multicolumn{6}{|c|}{ Marginal rate of return, $\$$ recovery $\$^{-1}$ investment } \\
\hline Conrad-2012 & - & 1.02 & 1.56 & - & -0.31 & 0.81 \\
\hline Corvallis-2012 & - & -0.89 & -1.41 & - & -1.17 & -2.14 \\
\hline Kalispell-2011 & - & 0.38 & 1.17 & - & 0.17 & 0.69 \\
\hline
\end{tabular}

(b)

\begin{tabular}{|c|c|c|c|c|}
\hline \multirow{2}{*}{ Site-year } & \multicolumn{2}{|c|}{ Unadjusted for protein } & \multicolumn{2}{|c|}{ Adjusted GY for protein } \\
\hline & Urea & ESN & Urea & ESN \\
\hline & \multicolumn{4}{|c|}{ Net return, $\$ \mathrm{ha}^{-1}$} \\
\hline Conrad-2011 & 612.68 & 134.32 & 502.94 & 43.38 \\
\hline Conrad-2013 & 533.88 & 374.48 & 479.36 & 276.45 \\
\hline \multirow[t]{2}{*}{ Kalispell-2011 } & 352.49 & 255.31 & 252.67 & 145.16 \\
\hline & \multicolumn{4}{|c|}{ Marginal profit, $\$ \mathrm{ha}^{-1}$} \\
\hline Conrad-2011 & - & -426.36 & & -459.56 \\
\hline Conrad-2013 & - & -85.00 & & -202.91 \\
\hline \multirow[t]{2}{*}{ Kalispell-2011 } & - & -22.78 & & -107.51 \\
\hline & \multicolumn{4}{|c|}{ Marginal rate of return, $\$$ recovery $\$^{-1}$ investment } \\
\hline Conrad-2011 & - & -8.20 & & -7.84 \\
\hline Conrad-2013 & - & -1.14 & & -1.73 \\
\hline Kalispell-2011 & - & -0.31 & & -0.45 \\
\hline
\end{tabular}

of eight site-years evaluated (Table 4). While preplant or atseeding applications of slow-release $\mathrm{N}$ products like ESN may be advantageous in winter wheat, it does not always result in improved GP in spring wheat. This may be mainly due to insufficient time for $\mathrm{N}$ release during shorter growing season.

Nitrogen uptake increased with increase in at-seeding $\mathrm{N}$ rates at seven of eight site-years; topdress $\mathrm{N}$ application increased $\mathrm{N}$ uptake in five of eight site-years (Table 6).

Nitrogen uptake was similar for all $\mathrm{N}$ sources, except for one site-year where slight increase in $\mathrm{N}$ uptake was observed with the blend application and for one site-year where the blend resulted in significantly greater $\mathrm{N}$ uptake (Table 6). It is possible that similar GY results achieved with urea, ESN, and blend were obtained because similar $\mathrm{N}$ losses (predominantly due to ammonia volatilization) have occurred from urea and ESN. As the soil temperatures increased, the rate of urea hydrolysis from the urea treatments increased [48]. At the same time, the dissolution of urea and its release from the
ESN capsules has also increased with higher soil temperatures.

This is where the controlled release versus delayed release discussion comes in, as an example; with average soil temperatures in Montana being approximately $68^{\circ} \mathrm{F}$ for June and July [29] it is expected that most of the urea has been released into the soil. In reality, we can expect comparable losses of $\mathrm{N}$ to occur from both urea and ESN treatments via ammonia volatilization. Thus, similar $\mathrm{N}$ amounts were available to wheat crop from all $\mathrm{N}$ sources applied.

The manufacturer's general recommendation for utilization of ESN for spring wheat in Great Plains region is application of $\mathrm{N}$ as $100 \% \mathrm{ESN}$ in the fall prior to seeding wheat the next spring [49]. Another commonly recommended application scenario is a spring application as a blend (40-75\% ESN + 25-60\% urea). Our findings showed that ESN and ureaESN blend performed well, but not better than urea alone. This is also supported by the partial budget economic analysis 
results. With GP-unadjusted revenue, by adopting ESN alone as $\mathrm{N}$ source, a farmer would lose money on investment but would recover costs by using urea-ESN blend. With GPadjusted revenue, farmer would not recover investment costs from ESN or blend compared with urea. The losses associated with ESN fertilization strategy make it uneconomical for spring wheat in dryland or irrigated spring wheat production system given the assumptions of the partial budget analysis.

Farmers need to be cautious when adopting ESN for improving economic return although environmentally the ESN may be beneficial. An important aspect of fertilizer management strategy is to carefully assess growing conditions that might affect profitability of fertilization.

\section{Competing Interests}

The authors declare that they have no competing interests.

\section{References}

[1] J. Bruinsma, "The resource outlook to 2050: by how much do land, water and crop yields need to increase by 2050?" in Proceedings of the Expert Meeting on How to Feed the World in 2050, Rome, Italy, June 2009.

[2] FAO, The State of Food Insecurity in the World (FAO), FAO, Rome, Italy, 2015.

[3] P. E. Fixen, "Potential biofuels influence on nutrient use and removal in the US," Better Crops, vol. 91, pp. 12-14, 2007.

[4] T. Roberts, "The role of fertilizer in growing the world's food," Better Crops, vol. 93, pp. 12-15, 2009.

[5] W. M. Stewart, Fertilizer and Food Production, International Plant Nutrition Institute (IPNI), Peachtree Corners, Georgia, 2009.

[6] W. Zhang and X. Zhang, "A forecast analysis on fertilizers consumption worldwide," Environmental Monitoring and Assessment, vol. 133, no. 1-3, pp. 427-434, 2007.

[7] M. Gupta and R. Khosla, "Precision nitrogen management and global nitrogen use efficiency," in Proceedings of the 11th International Conference on Precision Agriculture, Indianapolis, Ind, USA, July 2012.

[8] W. R. Raun and G. V. Johnson, "Improving nitrogen use efficiency for cereal production," Agronomy Journal, vol. 91, no. 3, pp. 357-363, 1999.

[9] O. S. Walsh, R. J. Christiaens, and A. Pandey, "Foliar-applied nitrogen fertilizers in spring wheat production," Crops and Soils, vol. 46, pp. 26-32, 2013.

[10] U. Singh, "Integrated nitrogen fertilization for intensive and sustainable agriculture," Journal of Crop Improvement, vol. 15, no. 2, pp. 259-288, 2006.

[11] USDA/NASS, Crop Production 2013 Summary, United State Department of Agriculture/National Agricultural Statistics Service, Washington, DC, USA, 2014.

[12] K. Girma and W. R. Raun, "Nutrient and water use efficiency," in Handbook of Soil Science: Resource Management and Environmental Impacts, P. M. Huang, Y. Li, and M. E. Sumner, Eds., pp. 405-421, CRS Press, Boca Raton, Fla, USA, 2nd edition, 2012.

[13] K. Olson-Rutz, C. Jones, and C. P. Dinkins, Enhanced Efficiency Fertilizers, Montana State University Extension, Bozeman, Mont, USA, 2011.
[14] A. Shaviv, "Advances in controlled-release fertilizers," Advances in Agronomy, vol. 71, pp. 1-49, 2001.

[15] W. Gordon, "Management of enhanced efficiency fertilizers," in Proceedings of the North Central Extension-Industry Soil Fertility Conference, Des Moines, Iowa, USA, November 2007.

[16] B. Gordon, "Nitrogen management for no-tillage corn and grain sorghum production," in Proceedings of the Great Plains Soil Fertility Conference, pp. 67-70, 2008.

[17] X. Gao, H. Asgedom, M. Tenuta, and D. N. Flaten, "Enhanced efficiency urea sources and placement effects on nitrous oxide emissions," Agronomy Journal, vol. 107, no. 1, pp. 265-277, 2015.

[18] J. L. Hatfield and R. T. Venterea, "Enhanced efficiency fertilizers: a multi-site comparison of the effects on nitrous oxide emissions and agronomic performance," Agronomy Journal, vol. 106, no. 2, pp. 679-680, 2014.

[19] S. A. Ebelhar, C. D. Hart, J. D. Hernandez, L. E. Paul, and J. J. Warren, "Evaluation of new nitrogen fertilizer technologies for corn," in Proceedings of the Illinois Fertilizer Conference, Peoria, Ill, USA, January 2007.

[20] Association of American Plant Food Control Officials (AAPFCO), Stablized Fertilizers, Association of American Plant Food Control Officials (AAPFCO), West Lafayette, Ind, USA, 2012.

[21] U. S. E. P. A. EPA, Inventory of U.S. Greenhouse Gas Emissions and Sinks: 1990-2013, Washington, DC, USA, EPA, 2015.

[22] A. D. Halvorson, C. S. Snyder, A. D. Blaylock, and S. J. Del Grosso, "Enhanced-efficiency nitrogen fertilizers: potential role in nitrous oxide emission mitigation," Agronomy Journal, vol. 106, no. 2, pp. 715-722, 2014.

[23] J. L. Hatfield and T. B. Parkin, "Enhanced efficiency fertilizers: effect on agronomic performance of corn in Iowa," Agronomy Journal, vol. 106, no. 2, pp. 771-780, 2014.

[24] M. L. Wilson, C. J. Rosen, and J. F. Moncrief, "A comparison of techniques for determining nitrogen release from polymercoated urea in the field," HortScience, vol. 44, no. 2, pp. 492-494, 2009.

[25] Agrium, Wheat Development and ESN Nitrogen Management, Agrium Inc, Calgary, Canada, 2014.

[26] R. Keller, "Slow release nitrogen: sustainability could be reason for using slow-release $\mathrm{N}$ formulations and additives," Ag Professional, 2010, http://www.agprofessional.com/agprofessional-magazine/slow-release_nitrogen_120018994.html.

[27] D. Franzen, "Slow-release nitrogen fertilizers and nitrogen additives for field crops," in Proceedings of the North Central Extension-Industry Soil Fertility, Des Moines, Iowa, USA, November 2010.

[28] M. Ruark, "Understanding the value of slow-release fertilizers," in Proceedings of the Wisconsin Crop Management Conference, Madison, Wis, USA, January 2010.

[29] O. S. Walsh and R. J. Christiaens, "US West: urea, ESN, and urea-ESN blends performed equally well as nitrogen sources for spring wheat," Crops and Soils, vol. 47, pp. 26-31, 2014.

[30] M. Alley, P. Scharf, D. Brann, W. Baethgen, and J. Hammons, "Nitrogen management for winter wheat: principles and recommendations," in Crop \& Soil Environmental Sciences, pp. 424429, 1999.

[31] R. E. Blackshaw, X. Hao, R. N. Brandt et al., "Canola response to ESN and urea in a four-year no-till cropping system," Agronomy Journal, vol. 103, no. 1, pp. 92-99, 2011.

[32] R. E. Blackshaw, X. Hao, K. N. Harker, J. T. O’Donovan, E. N. Johnson, and C. L. Vera, "Barley productivity response to 
polymer-coated urea in a no-till production system," Agronomy Journal, vol. 103, no. 4, pp. 1100-1105, 2011.

[33] A. D. Halvorson, S. J. Del Grosso, and C. P. Jantalia, "Nitrogen source effects on soil nitrous oxide emissions from strip-till corn," Journal of Environmental Quality, vol. 40, no. 6, pp. 17751786, 2011.

[34] R. H. McKenzie, A. B. Middleton, P. G. Pfiffner, and E. Bremer, "Evaluation of polymer-coated urea and urease inhibitor for winter wheat in southern Alberta," Agronomy Journal, vol. 102, no. 4, pp. 1210-1216, 2010.

[35] B. R. Golden, N. A. Slaton, R. J. Norman, C. E. Wilson Jr., and R. E. Delong, "Evaluation of polymer-coated urea for directseeded, delayed-flood rice production," Soil Science Society of America Journal, vol. 73, no. 2, pp. 375-383, 2009.

[36] M. L. Wilson, C. J. Rosen, and J. F. Moncrief, "Potato response to a polymer-coated urea on an irrigated, coarse-textured soil," Agronomy Journal, vol. 101, no. 4, pp. 897-905, 2009.

[37] C. M. Hutchinson, "Influence of a controlled release nitrogen fertilizer program on potato (Solanum tuberosum L.) tuber yield and quality," Acta Horticulturae, vol. 684, pp. 99-102, 2005.

[38] B. J. Winer, D. R. Brown, and K. M. Michels, Statistical Principles in Experimental Design, vol. 2, McGraw-Hill, New York, NY, USA, 1971.

[39] O. Schabenberger, T. G. Gregoire, and F. Kong, "Collections of simple effects and their relationship to main effects and interactions in factorials," The American Statistician, vol. 54, no. 3, pp. 210-214, 2000.

[40] G. Snedecor and W. Cochran, Statistical Methods, Oxford and IBH Publishing Co, Calcutta, India, 8th edition, 1994.

[41] T. Alimi and V. Manyong, Partial Budget Analysis for on-farm Research, vol. 65, IITA, 2000.

[42] M. E.-D. Soha, "The partial budget analysis for sorghum farm in Sinai Peninsula, Egypt," Annals of Agricultural Sciences, vol. 59, no. 1, pp. 77-81, 2014.

[43] West-Con-Cooperative, "Spring wheat proteins," https://s3 .amazonaws.com/media.agricharts.com/sites/591/PDFs/SprProteins.pdf.

[44] USDA/AMS-WY, “Montana daily cash grain prices," http:// www.ams.usda.gov/mnreports/bl_gr110.txt.

[45] Agrium, "ESN return on investment," http://www.smartnitrogen.com/roi-calculator.

[46] H. S. Weber and D. B. Mengel, "Use of nitrogen management products and practices to enhance yield and nitrogen use efficiency in no-till corn," in Proceedings of the North Central Extension-Industry Soil Fertility Conference, vol. 25, pp. 18-19, Des Moines, Iowa, USA, 2009.

[47] G. Randall and J. Vetsch, "Fall and spring-applied nitrogen sources for corn in Southern Minnesota," Tech. Rep., University of Minnesota Southern Research and Outreach Center, Waseca, Minn, USA, 2009.

[48] D. Yadav, V. Kumar, M. Singh, and P. Relan, "Effect of temperature and moisture on kinetics of urea hydrolysis and nitrification," Australian Journal of Soil Research, vol. 25, no. 2, pp. 185-191, 1987.

[49] O. Walsh, A. Pandey, and R. Christiaens, "Environmentally smart nitrogen performance in northern great plains spring wheat production systems," in Proceedings of the Western Nutrient Management Conference, vol. 11, Reno, Nev, USA, 2015. 


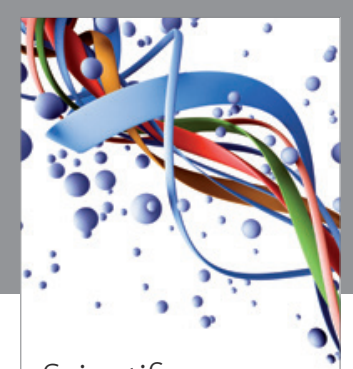

Scientifica
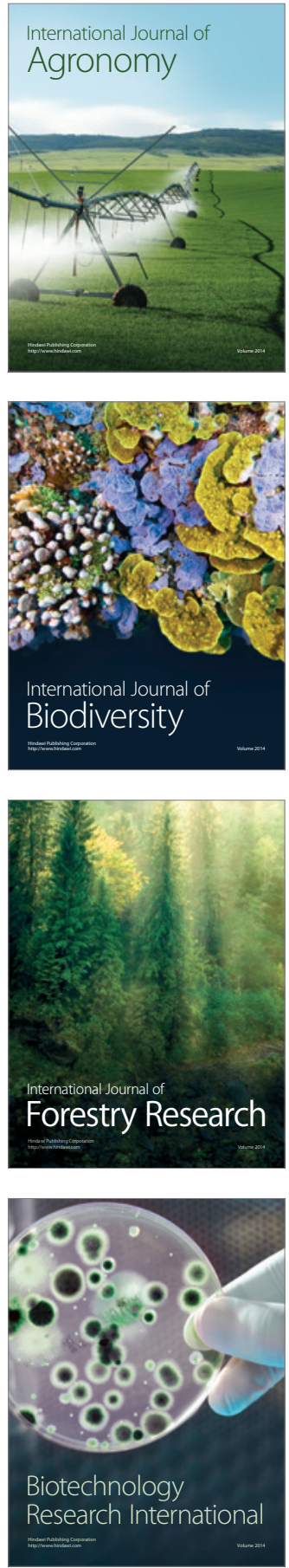
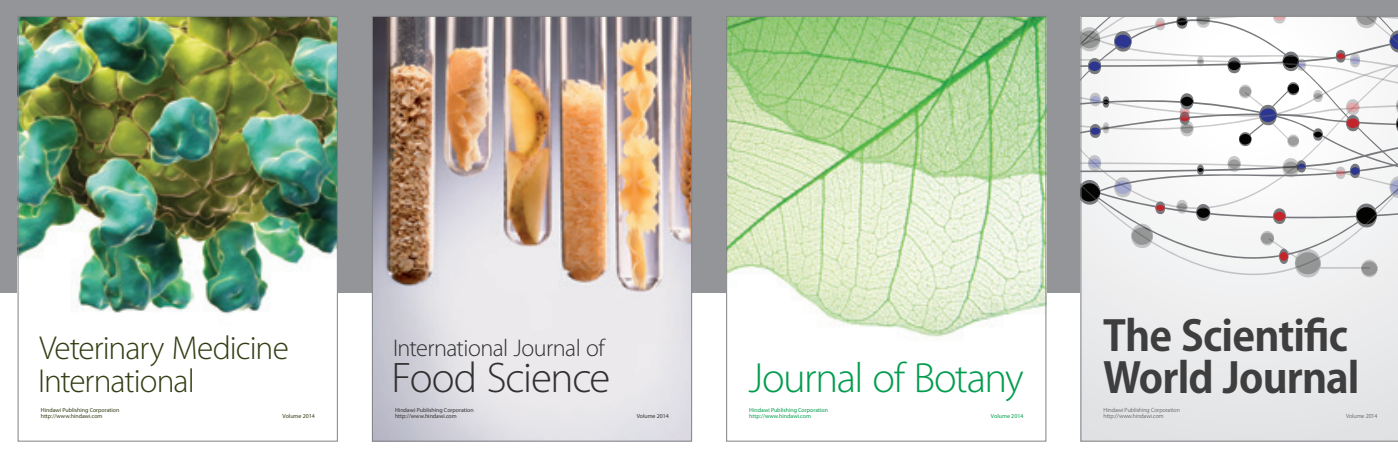

The Scientific

\section{World Journal}

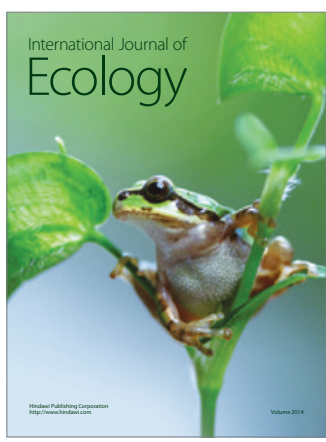

\section{Hindawi}

Submit your manuscripts at

http://www.hindawi.com
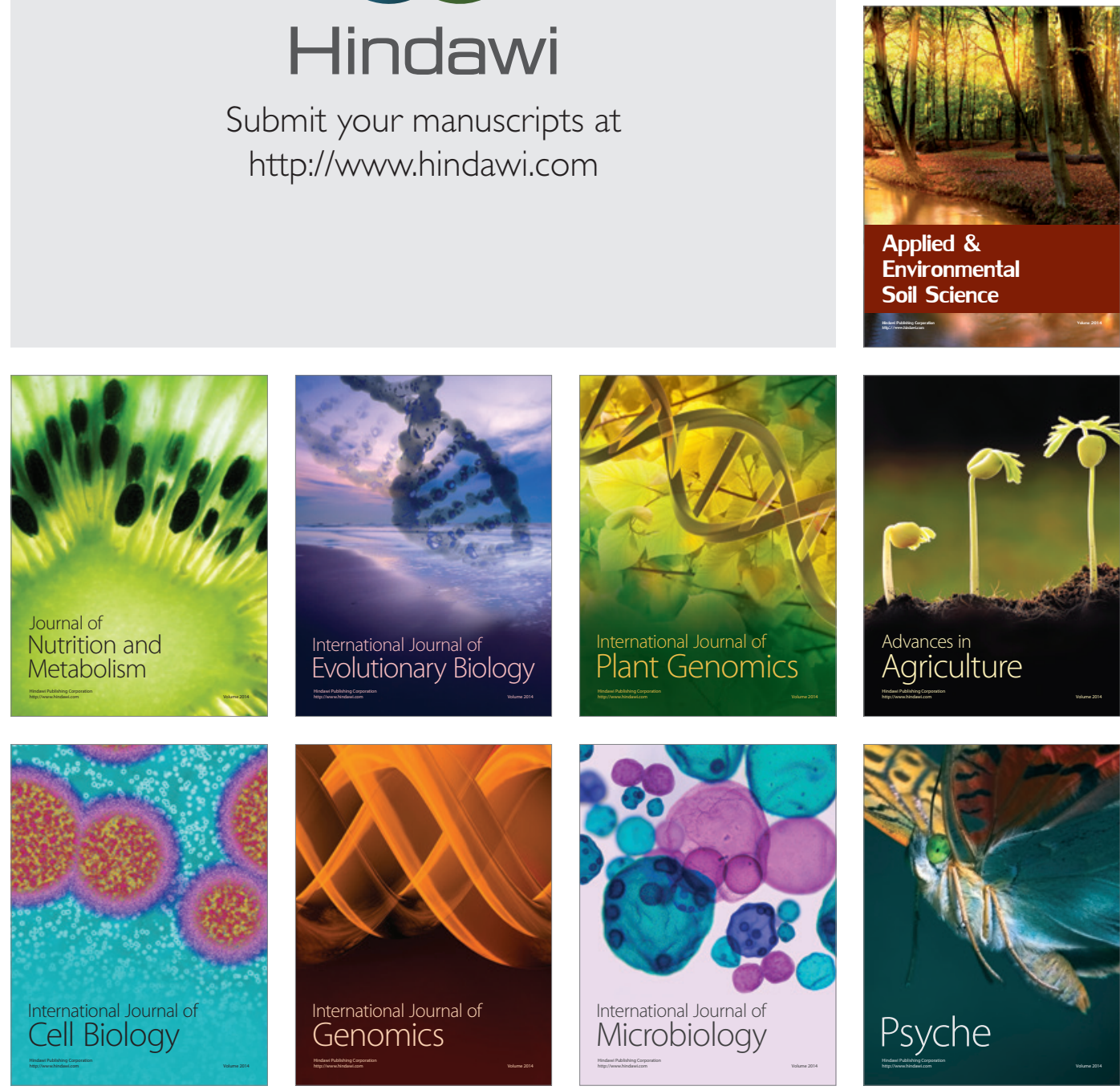
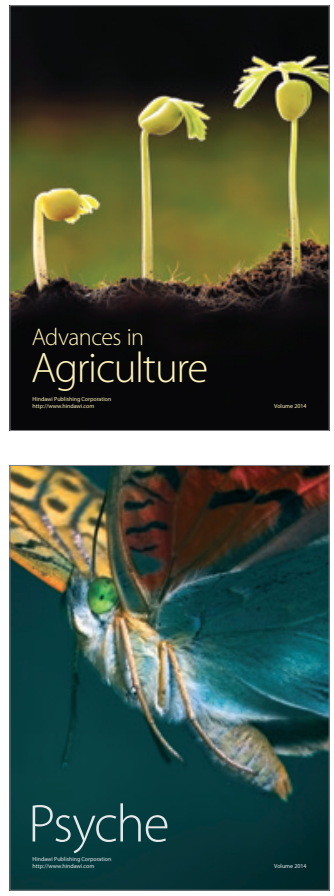